\title{
Options for Corporate Tax Reform in 2017
}

\author{
The following was adapted from remarks originally \\ given at the Fall 2017 meeting of the Brookings Panel \\ on Economic Activity on September 8, 2017.
}

\begin{abstract}
T he U.S. corporate tax system is wrought with problems that have accumulated over many decades. The Tax Reform Act of 1986 (TRA86) provided a major overhaul of the personal income tax, reducing the top rate from 50 percent to 28 percent while maintaining revenue and distributional neutrality. But it did little to improve the corporate tax system. Indeed, TRA86 actually raised corporate tax revenue in order to pay for reductions in personal rates. Moreover, the specific changes in depreciation rules brought about by TRA86 reduced investment incentives, biasing the tax system in favor of owner-occupied housing instead of productivityenhancing investment in business structures and equipment.

The House Republican plan, which was developed while Paul Ryan was chairman of the Ways and Means Committee, proposes to do five important things: (i) reduce the overall corporate tax rate; (ii) correct the tax treatment of the profits earned by the foreign subsidiaries of U.S. corporations; (iii) replace the traditional corporate tax with some form of cash-flow corporate tax; (iv) deal with pass-through businesses in an efficient and equitable way; and (v) avoid increasing the fiscal deficit while doing these things. ${ }^{1}$ I briefly comment on each of these five goals below.
\end{abstract}

Conflict of Interest Disclosure: The author did not receive financial support from any firm or person for this paper or from any firm or person with a financial or political interest in this paper. He is currently not an officer, director, or board member of any organization with an interest in this paper. No outside party had the right to review this paper before publication.

1. Tax Reform Task Force, "A Better Way: Our Vision for a Confident America" (Washington: U.S. House of Representatives, 2016). 


\section{Reducing the Corporate Tax Rate}

The U.S. federal corporate tax rate is presently at 35 percent, the highest among all the major industrialized countries. In addition, individual U.S. states levy corporate taxes at an average rate of 9 percent. Because state taxes are deductible when calculating federal taxable income, the overall corporate tax rate is closer to 40 percent. In contrast, the average rate among countries that belong to the Organization for Economic Cooperation and Development is about 25 percent.

The effective corporate tax rate is reduced by accelerated depreciation of investment in plants and equipment and by the deduction of nominal interest payments rather than the lower real interest payments. These are similar to the practices in other industrial countries.

The House Republican plan calls for reducing the statutory rate from 35 percent to 20 percent. The Trump presidential campaign called for reducing it to 15 percent.

Reducing the corporate tax rate would attract funds to the corporate sector from other uses, such as owner-occupied housing and agriculture. It would also attract foreign capital to the U.S. corporate sector. These shifts would increase the efficiency with which capital is allocated across sectors and across international markets. The increased capital in the U.S. business sector would raise the productivity and real wages of American workers. It would also increase real GDP growth as the corporate capital stock grows.

Although lowering the corporate tax rate would have substantial economic benefits, it would also have a significant budgetary cost. Because the corporate income tax presently accounts for about 1.6 percent of GDP, cutting the rate from 35 percent to about half that level would directly reduce revenue by about 0.8 percent of GDP. Though this would be partly offset by the faster economic growth and by the rise in real wages and profits, there would still be an increase in the budget deficit. To limit the revenue loss and achieve a long-run balanced budget, the statutory rate will probably need to be reduced to no less than 25 percent, a point to which I return below.

\section{Correcting the Tax Treatment of the Profits Earned by the Foreign Subsidiaries of U.S. Corporations}

The United States is virtually alone in how it taxes the profits earned by the foreign subsidiaries of domestically based corporations. Consider a foreign subsidiary of a U.S. corporation that earns profits in Ireland. It pays 
the Irish government a 12 percent tax and is then free to do what it wants with the after-tax profits. It can invest them in Ireland, or hold them in financial assets, or invest them in any other country in the world. But if it brings these after-tax profits back to the United States, it must pay the U.S. corporate income tax of 35 percent, minus the 12 percent paid in Ireland, before it can either invest them in the United States or distribute them to shareholders.

Not surprisingly, most American corporations decide not to repatriate these after-tax profits. The U.S. Treasury Department estimates that American corporations have kept roughly $\$ 2.5$ trillion in after-tax profits outside the United States; about half of this $\$ 2.5$ trillion is held in the form of financial assets, while the other half is invested in operating businesses outside the United States.

In contrast to the United States, other countries follow what is called the "territorial method" of taxing the profits of their domestic corporations' foreign subsidiaries. Profits can be repatriated and invested in the home country after paying either no tax or a very small corporate tax-such as 5 to 10 percent-on repatriated profits.

American multinational corporations that do not want to repatriate the profits of their foreign subsidiaries have two options if they do not want to earn only the low rate of return available on financial assets: They can invest these profits in offshore businesses, or they can hold these profits in financial assets and borrow an equal amount at home to invest in the United States. The fact that about half the $\$ 2.5$ trillion in unrepatriated funds is invested in foreign operating businesses shows that U.S. multinationals prefer to invest a substantial part of their foreign subsidiary profits in overseas businesses. Their reluctance to borrow in the United States in order to invest at home may reflect the equity market's negative view of increased debt on the company's balance sheet, even if it is in principle balanced by the holding of bonds or bank deposits in the foreign subsidiary. This behavior implies that a shift to a territorial tax system will cause multinational corporations to repatriate more of the profits of their foreign subsidiaries rather than investing them abroad.

A shift by the United States to a territorial system of taxation would therefore have very substantial favorable effects. Much of the $\$ 2.5$ trillion in funds that have been accumulated abroad would eventually be repatriated and invested in the United States. The half of this \$2.5 trillion that is now invested in overseas operating businesses could only be sold gradually, but U.S. firms could borrow against these offshore assets and bring these funds home. In addition, the future profits of U.S. corporations' 
foreign subsidiaries would also be more likely to be repatriated instead of being invested in new companies outside the United States. But even if paid out as dividends or used to buy back shares, most of these funds would find their way into new investments by other firms. In this way, the shift to a territorial system would have favorable effects similar to a reduction in the corporate tax rate-such as raising capital per worker, increasing productivity and real wages, stimulating higher growth, and producing higher taxable incomes.

A U.S. shift to a territorial system would also increase foreign companies' incentives to invest in the United States and to establish U.S. headquarters, knowing that they could repatriate foreign profits for further investment in the United States or elsewhere.

A territorial system would raise corporate tax revenue for the United States by shifting more profits to be invested in the United States. The House Republican tax plan also calls for a "deemed repatriation tax" on the $\$ 2.5$ trillion of previously untaxed profits, providing a significant short-term boost to corporate tax receipts.

But a shift to a territorial system would also potentially have adverse effects. It could encourage U.S. firms to establish subsidiaries in "tax shelter" countries with extremely low tax rates in order to earn profits there and then return them to the United States with little or no further tax. It could encourage firms to shift profits to such tax shelters using transfer pricing or debt transactions. These would require careful monitoring or special rules for tax shelter countries.

A permanent shift to a territorial system would be quite different from the one-time repatriation holiday that was tried in 2004, when companies were allowed to repatriate foreign subsidiaries' profits with the understanding that these funds would be invested in the United States. Many of the repatriated funds were nevertheless used for share buybacks and dividends. It is not possible, however, to know how much of the funds that were paid out as dividends or share buybacks were then used to finance investments in other firms. Moreover, a permanent shift to a territorial system would create different incentives than a one-time repatriation holiday.

\section{Adopting a Cash-Flow Corporate Tax}

Several years ago, at the annual meeting of the American Economic Association, I proposed replacing the United States' corporate income tax with a cash-flow tax. With such a cash-flow tax, each company's tax base would be increased by any inflow of cash-whether from product sales, borrowing, or 
the issuance of equity - and would be decreased by any outflow of cashwhether from the cost of inputs, from repaying debt, paying interest and dividends, or buying back shares. Like many good ideas, it was not pursued at the time. So I will not comment on its potential virtues.

There is now discussion of a so-called destination-based cash-flow tax (DBCFT), which has a very different structure. ${ }^{2}$ There are three components to this DBCFT: First, companies would get an immediate write-off for all investments in equipment and structures; second, companies would not be allowed to deduct interest on new loans; and third, there would be a deduction for export sales and an extra tax on imports. I think that in some longrun steady state, this would be equivalent to the simpler cash-flow tax that I proposed earlier.

Allowing an immediate write-off of all expenditures for structures and equipment would provide a strong incentive for such productivityincreasing investments. It would also cause a very large loss of revenue. The Tax Foundation estimates that the cost of expensing for corporate investments would be some $\$ 2$ trillion over the first 10 years. ${ }^{3}$

Eliminating interest deductions on new loans would raise significant revenue but would be difficult to implement. When is a loan "new," rather than a rollover of an existing loan? How should leasing be distinguished from borrowing? How should loans of foreign subsidiaries be treated?

The firms that gain from expensing would be different from those that lose from eliminating interest deductions, making it politically difficult to enact such a pair of proposals.

To complete the similarity to a true cash-flow tax, the DBCFT plan adds a border-adjustment component: All imports would be subject to an additional tax at the corporate tax rate, while all exports would be granted an additional deduction at that rate in calculating table profits. Although this might look like a plan to increase exports and decrease imports, it would not be. As economists understand, an improvement in the trade balance requires a change in the difference between national saving and national investment. The fundamental economic relation is that exports minus imports equal national saving minus national investment. Because the DBCFT implies no change in saving or investment, there should be no

2. Alan Auerbach's paper in the present volume discusses the destination-based cash-flow tax in detail.

3. Kyle Pomerleau, "Details and Analysis of the 2016 House Republican Tax Reform Plan," Fiscal Fact no. 516 (Washington: Tax Foundation, 2016). 
change in imports and exports, despite the tax on imports and the subsidy to exports. The textbook resolution of this apparent paradox is that the exchange rate for the dollar would rise enough to make the value of foreign goods when they reach the United States lower by just enough to balance the effect of the tax on imports. The same would apply to the subsidy on exports.

In principle, therefore, the border-adjustment tax would have no net effect on the prices paid by U.S. consumers or the prices received by U.S. exporters. There are, of course, reasons why the full textbook adjustment of the exchange rate might not happen in practice. Importers and retailers fear that they might lose from the tax on imports. Because there would be no potential gain for them if the border-adjustment tax were enacted and a risk of a serious loss, they have been opposing it politically, arguing that it would raise prices for American consumers.

The opponents of the border-adjustment tax system appear to have won the political battle. A statement by the Republican congressional leaders who deal with taxes has explicitly withdrawn support, and my judgment is that Congress will not enact the border-adjustment tax or any other part of the DBCFT plan. ${ }^{4}$

\section{Dealing with Pass-Through Businesses}

About half of business activity in the United States is conducted by organizations that are not traditional $\mathrm{C}$ corporations. These include $\mathrm{S}$ corporations (the income of which is added to other personal income for personal income tax purposes), partnerships, and sole proprietorships.

If the top rate of the personal income tax were reduced from the current 39.6 percent to 35 percent, the pass-through entities would pay a tax on their profits under current law at the level of their personal tax rate, or 35 percent. The owners of such businesses complain that this would be much higher than the proposed 20 percent rate that would be paid by regular $\mathrm{C}$ corporations.

The representatives of small businesses and other pass-through entities are therefore lobbying to have a special lower rate for these entities. Doing so would create an incentive for salaried individuals who are able to do so to incorporate their activities as $\mathrm{S}$ corporations or other forms that

4. Paul Ryan, Mitch McConnell, Steven Mnuchin, Gary Cohn, Orrin Hatch, and Kevin Brady, "Joint Statement on Tax Reform," July 27, 2017. 
qualify for the proposed lower tax rate in order to take advantage of that new lower rate.

The gap between the proposed personal income tax rate of 35 percent and the proposed corporate rate of 20 percent exaggerates the true effective difference between owners of $\mathrm{C}$ corporations and owners of pass-through businesses. The full effective rate on corporate businesses includes not just the corporate tax rate but also the additional tax that must be paid by shareholders when after-corporate-tax profits are distributed to the owners of the corporation.

Here is the relevant arithmetic: A pass-through entity with $\$ 100$ in profits would have a net-of-tax income of $\$ 65$. A C corporation with the same $\$ 100$ in pretax profits would pay the new 20 percent corporate rate, producing an after-tax profit of $\$ 80$. If this $\$ 80$ were paid out as dividends, the net income to the owner would be less than $\$ 65$ if the tax on dividends exceeds 18.75 percent. Even with a 15 percent tax on dividends, the $\$ 80$ paid out as dividends would yield a net income of just $\$ 68$, and therefore more than the income of the pass-through owner. If, instead, the after-tax profits were retained until the corporation was dissolved, the accumulated profits would, under current law, be subject to tax at both the corporate and personal levels. In short, the pass-through entities have a very weak case for a significantly lower tax rate.

\section{Avoiding an Increase in the Fiscal Deficit}

The reduction of the corporate rate and some of the other potential changes could significantly increase the fiscal deficit. The House Republican plan originally proposed to solve this with a border-adjustment tax.

A border-adjustment tax would have raised substantial revenue because a tax on imports would raise more revenue than a subsidy on exports would lose. This is because the United States imports about 15 percent of GDP and exports about 12 percent. With a 20 percent corporate rate applied to both, the net revenue effect would be to raise revenue by 20 percent of 3 percent of GDP, or about 0.6 percent of GDP. At today's level of GDP, that is about $\$ 120$ billion, probably enough to offset the revenue loss due to the corporate rate reduction. Although, in theory, the U.S. trade deficit will need to be reversed at some date in the future, it is worth noting that the U.S. trade deficit has persisted for more than 30 years, and will continue as long as foreign savers want to invest in U.S. assets.

A challenge for corporate tax reform is therefore how to replace the revenue that will not be raised if the border-adjustment tax is not enacted. 
More generally, the combination of corporate and personal tax reforms can only be enacted without the support of the Senate Democrats by using the budget process known as reconciliation. Reconciliation allows the tax legislation to pass with just a simple majority in the Senate, enabling the 52 Republican senators to pass their proposed plan. But the reconciliation process can be used only if there is no increase in the projected budget deficit beyond the first 10 years.

Even with dynamic scoring, which recognizes the extra revenue from faster economic growth, avoiding a deficit increase after the first 10 years will require limiting the size of the corporate rate decrease and offsetting the reductions in the personal income tax by eliminating or limiting a variety of personal deductions and exclusions.

I believe this feature of the reconciliation process will cause the Republican leadership to develop plans that do in fact avoid any increase in the fiscal deficit after the first 10 years. If so, the budget projections will show some increase in the deficit in the next 10 years, but not after that. 